\title{
Dinamika Pemilihan Kepala Daerah Berdasarkan Peraturan Perundang-Undangan di Indonesia
}

\section{Husein Muslimin}

Husein Muslimin; Fakultas Hukum Universitas Merdeka Malang; Jl. Terusan Raya Dieng No.62-64; Malang; Indonesia.

\begin{tabular}{l}
\hline A R T I C L E I N F O \\
\hline Article history: \\
Received 2019-04-29 \\
Received in revised form \\
2019-06-12 \\
Accepted 2019-07-01 \\
\hline
\end{tabular}

Kata kunci:

Demokrasi, Calon Kepala Daerah, Pemilihan Langsung.

\section{Keywords:}

Democracy, The Head of The

Region Candidate, The Direct

Election.

\section{Citation:}

Muslimin, H. (2019). Dinamika

Pemilihan Kepala Daerah Berdasarkan Peraturan Perundang-Undangan di Indonesia. Jurnal Cakrawala Hukum, 10(1).

doi:10.26905/idjch.v10i1.3187

\begin{abstract}
Abstrak
Pemilihan kepala daerah secara langsung, dengan Undang Undang Nomor 32 Tahun 2004 pemilihan kepala daerah dimulai dari penentuan calon yang diusulkan oleh partai politikatau gabungan partai politik secara berpasangan dengan calon wakilnya untuk dipilih secara langsung oleh rakyat di daerah yang bersangkutan. Sistem pencaloanan tersebut dianggap kurang representatif karena ketergantungan calon kepada partai atau gabungan partai, maka melalui Undang Undang Nomor 12 Tahun 2008 sebagai perubahan kedua atas Undang Undang Nomor 32 Tahun 2004 memberikan kesempatan pasangan calon dari perseorangan dengsn syarat tertentu, sistem ini memerlukan biaya besar dan menguras' energi, politik uang juga masih terjadi bahkan lebih besar karena sasarannya adalah rakyat sebagai pemilih. Kelemahan-kelemahan dalam undangundang tersebut kemudian berusaha diatasi melalui Undang-undang Nomor 8 Tahun 2015 dengan cara menetapkan pemilihan satu putaran, larangan partai politik atau gabungan partai politik untuk menerima segala mahar dari pasangan calon yang diusung, dan adanya konsepsi pemilihan kepala daerah serentak secara nasional.
\end{abstract}

\begin{abstract}
Direct regional head election, with Law Number 32 Year 2004 the regional head election starts from the determination of candidates proposed by political parties or a combination of political parties in pairs with their representative candidates to be elected directly by the people in the area concerned. The counting system is considered to be less representative because of the candidate's dependence on the party or party combination, then through Law Number 12 Year 2008 as the second amendment to Law Number 32 Year 2004 provides the
\end{abstract}


opportunity for candidate pairs from individuals with certain conditions, this system requires large costs and drains 'energy, money politics also occur even bigger because the target is the people as voters. Weaknesses in the law are then sought to be overcome through Law Number 8 of 2015 by determining one round of elections, the prohibition of political parties or a combination of political parties to accept all the dowry from the candidate pairs promoted, and the conception of regional head elections simultaneously nationally.

\section{Latar Belakang}

Demokrasi merupakan pilihan yang paling tepat dan diyakini sebagai sistem yang akan memberikan kepuasan semua pihak. UNESCO pada awal tahun 1950an melakukan studi tentang demokrasi yang pada saat itu mengumpulkan lebih dari 100 (seratus) sarjana baik yang berasal dari barat maupun dari timur yang pada akhirnya menghasilkan kesamaan pandangan dan anggapan yakni menyepakati dan sedikitpun tidak ada penolakan dari mereka, bahwa demokrasi dianggap sebagai perwujudan yang paling tepat dan ideal untuk semua organisasi politik dan organisasi sosial modern (Rais, 1986). Sefaham dengan hal tersebut diatas H.S. Tisnanta mengatakan, demokrasi merupakan credo suci dalam penyelenggaraan pemerintahan negara modern dalam pergaulan dunia internasional.

Hal itu didasarkan pada alasan bahwa sistem demokrasi dipercaya sebagai suatu sistem yang mencerminkan mekanisme politik yang dianggap mampu menjamin adanya pemerintah yang tanggap terhadap preferensi dan keinginan warga negaranya (Muladi, 2005). Namun demikian kendatipun demokrasi diyakini sebagai sistem yang terbaik tidak ada jaminan bahwa pemerintahan yang demokratis bebas dari korupsi, bahkan tidak menutup kemungkinan pelaksanaan demokrasi terutama yang berkaitan dengan pemilihan pemimpin justru menjadi salah satu sebab terjadinya korupsi, tetapi pemerintahan tersebut tetap sebagai pemerintahan yang demokratis.
Joseph Schumpeter dalam memahami demokrasi sebagai bentuk pemerintahan, salah satu teori yang digunakan adalah metode demokratis yakni prosedur kelembagaan untuk mencapai keputusan politik yang didalamnya individu memiliki kewenangan untuk membuat keputusan melalui perjuangan kompetitif dalam rangka memperoleh suara rakyat. Dengan mengikuti tradisi Schumtarian, Hantington mendefinisikan sistem politik abad 20 mengimplikasikan sebagai demokrasi yang para pembuat keputusan kolektif yang paling kuat dalam sistem itu, dipilih melalui pemilihan umum yang adil, jujur, dan berkala, didalam sistem itu para calon bersaing secara bebas untuk memperoleh suara, dan sebagian besar penduduk berhak memberikan suara, dengan demikian tampak adanya dua unsur dalam demokrasi yakni kontes dan partisipasi. Demokrasi juga mengimplikasikan adanya kebebasan sipil dalam politik yaitu kebebasan untuk berbicara, menulis, berkumpul, dan berorganisasi yang dibutuhkan untuk debat politik maupun pelaksanaan kampanye-kampanye pemilihan (Huntington, 2001).

Kontes dan partisipasi dalam proses demokrasi akan dipengaruhi oleh tiga unsur yang terlibat didalamnya yakni, peserta kontes atau caloncalon pemimpin yang bersaing untuk merebut dukungan, penduduk sebagai pemilik suara, dan panitia yang menyelenggarakan kontes tersebut. Ketiga komponen tersebut harus memiliki komitmen yang sama, artinya masing-masing komponen tersebut sadar bahwa yang dilakukan adalah suatu 
proses di dalam negara demokrasi untuk mewujudkan negara yang sejahtera, adil dan makmur.

Negara Indonesia melalui Undang Undang Dasar Negara Republik Indonesia Tahun 1945 (UUD NRI 1945) sejak awal berdirinya oleh para pendiri negara memang didesain sebagai negara yang berkedaulatan rakyat sebagaimana dinyatakan dalam pasai 1 ayat (1) UUDNRI 1945, bahwa kedaulatan ada padarakyat yang dilaksanakan oleh Majelis Permusyawaratan Rakyat. Kertentuan ini setelah UUDNRI diamandemen juga mengalami perubahan yang cukup mendasar yakni, kedaulatan berada di tangan rakyatdan dilaksanakan menurut Undang-Undang Dasar.

Pilihan bentuk negara dengan kekuasaan tertinggi dalam negara berada di tangan rakyat ini bukan sesuatu yang kebetulan, dan asas ini juga bukan hanya disesuaikan dengan meggunakan mitos negara modern yang selalu menggunakan sistem perwakilan untuk melaksanakan kedaulatan rakyat, melainkan benar-benar diwarnai oleh cara hidup masyarakat Indonesia yang sudah sejak lama, sebagaimana tercermin dalam kehidupan desa yang sudah dari dulu hidup berdasarkan kedaulatan raktat (Attamimi, 1990).

Sebagai konsekuensi dari pasal 1 ayat (2) yang kemudian diikuti oleh pasal-pasal yang lain, mengamanatkan pelaksanaan pemerintahan yang demokratis mulai dari pemerintahan pusat sampai di daerah dalam berbagai aspeknya, termasuk pengisian struktur pemegang pemerintahan baik ditingkat pusat maupun di daerah seperti, gubernur, bupati dan walikota yang kesemuanya harus melibatkan rakyat baik langsung maupun tidak langsung. Melalui beberapa undang-undang pelibatan rakyat yang merupakan partisipasi rakyat terhadap pembentukan kepala daerah mengalami perubahan-perubahan sesuai dengan perkembangan jaman, sehingga menampakkan adanya dinamika khususnya dalam pengisian jabatan kepala daerah.

\section{Metode}

Penelitian ini menggunakan penelitian normatif empiris. Penelitian normatif-empiris yaitu penelitian yang dilakukan untuk menelaah kaidah hukum normatif yang dilihat dari segi penerapannya. Penelitian normatif-empiris ini dilakukan untuk mencermati bagaimana dinamika pemilihan kepala daerah berdasarkan Undang-undang yang pernah berlaku di Indonesia serta kelemahan-kelemahanya dalam setiap dinamika pemilihan kepala daerah berdasarkan Undang-undang yang pernah berlaku di Indonesia.

Adapun perspektif yang penulis gunakan dalam mengkaji bagaimana dinamika pemilihan kepala daerah berdasarkan Undang-undang yang pernah berlaku di Indonesia serta kelemahan-kelemahanya dalam setiap dinamika pemilihan kepala daerah berdasarkan Undang-undang yang pernah berlaku di Indonesia. pada penelitian ini menggunakan pendekatan yuridis normatifempiris.

Penelitian ini menggunakan pendekatan yuridis karena berpijak pada ketentuan-ketentuan hukum sebagai dasar normatif, sedangkan pendekatan lunsur empiris, karena dalam penelitian ini melakukan peninjauan pelaksanaan ketentuan yuridis tersebut, termasuk mengkaji beberapa hal yang berpengaruh pada pelaksanaan ketentuan hukum yang berlaku di masyarakat di telah dari sisi empiris.

\section{Pembahasan}

\subsection{Pemilihan Kepala Daerah Berdasarkan Undang-Undang yang Pernah dan Sedang Baerlaku.}

Jika yang kita bicarakan adalah pemilihan kepala daerah yang tidak terlepas dari pemerintahan itu sendiri, maka sesungguhnya pemerintah daerah itu sudah ada semenjak pemerintahan Belanda yang hirarkinya tidak seperti sekarang. 
Dimulai dari yang paling atas yakni gewest (provinsi) yang dipimpin oleh gubernur, karesidenan yang dipimpin residen, afdeling dipimpin asisten residen, kabupaten dipimpin bupati, kemudian ada district atau kawedanan yang dipimpin wedana, dan onderdistrict yang dipimpinoleh camat. Pemimpin disemua tingkatan ditentukan oleh pemerintah kolonial tanpa melalui pemilihan, dan setelah itu diganti oleh pemerintahan Jepang yang hanya mengubah istilah jabatan-jabatannya saja (viva.co.id, 2016).

Masa kemerdekaan dengan undang-undang Nomor 1 tahun 1945 tentang Kedudukan Komite Nasional Daerah, kepala daerah sebagai pemimpin komite nasional daerah, sekaligus menjadi anggota dan ditetapkan sebagai ketua badan perwakilan daerah. Undang-Undang Dasar Negara RI tahun 1945 kemudian berganti dengan Konstitusi RIS 1949 yang mengubah bentuk negara menjadi negara serikat, namun pada tahun 1950 bentuk negara kembali pada negara kesatuan dan disini tingkatan pemerintah daerah diubah tingkat I tingkat II, dan daerah tingkat III yakni kecamatan yang dipimpin seorang camat.

Dekrit Presiden tanggal 5 juli 1959, diberlakukan kembali UUDRI 1945 yang kemudian dikeluarkan Undang-Undang Nomor 18 tahun 1965, di dalam undang-undang ini Presiden atau Menteri Dalam Negeri mengangkat calon-calon kepala daerah yang diajukan oleh DPRD.

Undang-Undang Dasar Negara Republik Indonesia (UUDNRI 1945) sebelum dilakukan perubahan, mengatur tentang pemerintahan daerah dalam pasal 18 yang hanya terdiri dari satu ayat menyebutkan bahwa, pembagian daerah Indonesia atas daerah besar dan kecil, dengan bentuk susunan pemerintahannya ditetapkan dengan undang-undang, dengan memandang dan mengingat dasar permusyawaratan dalam sistem pemerintahan negara, dan hak-hak asal-usul dalam daerahdaerah yang bersifat istimewa. Dari pasal 18 UUDNRI tersebut dapat disarikan beberapa hal sebagai berikut: a. pembagian daerah kedalam daerah besar dan kecil;

b. susunan pemerintahan yang demokratis;

c. menghargai hak asal-usul dalam daerah-daerah yang bersifat istimewa;

d. dituangkan atau dilaksanakan dengan undang undang.

Pasal 18 UUDNRI tersebut kemudian menjadi dasar dikeluarkannya undang-undang pemerintahan daerah yakni, Undang-Undang Nomor 5 tahun 1974 tentang Pemerintahan di Daerah yang berlaku sampai tahun 1999. Dalam hal pembagian wilayah Negara Republik Indonesia kedalam daerah besar dan kecil, Undang-Undang Nomor 5 tahun 1974, menyebutkan bahwa dalam menyelenggarakan pemerintahan, wilayah Negara Kesatuan Republik Indonesia dibagi dalam daerahdaerah Otonom dan wilayah-wilayah Administratif. Ketentuan ini jika dihubungkan dengan pasal 3 undang-undang yang sama menimbulkan Daerah Tingkat I dan Daerah Tingkat II, pada ayat 1 disebutkan, dalam rangka pelaksanaan asas desentralisasi dibentuk dan disusun Daerah Tingkat I dan Daerah Tingkat II. Dengan adanya Daerah Tingkat I dan Derah Tingkat II, maka secara otomatis terbentuk pula pemerintah di daerah tersebut sebagai pelaksana pemerintahan di daerah.

Pemerintah Daerah sebagaimana disebutkan dalam pasal 13 Undang-undang Nomor 5 tahun 1974 adalah, Kepala Daerah dan Dewan Perwakilan Rakyat Daerah (DPRD). Kepala Daerah dipilih oleh Dewan Perwakikan Rakyat Daerah dan pengangkatannya dilakukan oleh pejabat yang berwenang atas usul Dewan Perwakilan rakyat Daerah, sedangkan untuk Wakil Kapala Daerah diusulkan oleh Dewan Perwakilan Rakyat Daerah kepada pejabat yang berwenang. Untuk Kepala Daerah Tingkat I dicalonkan dan dipilih oleh DPRD I dari sedikit-dikitnya 3 (tiga) orang dan sebanyak-banyaknya 5 (lima) orang calon yang telah dimusyawarahkan dan disepakati bersama antara Pimpinan 
DPRD/Pimpinan Fraksi-Fraksi dengan Gubernur Kepala Daerah (pasal 15 ayat (1)).

Hasil pemilihan tersebut diajukan kepada Presiden melalui Menteri Dalam Negeri sedikitdikitnya 2 (dua) orang untuk diangkat salah satu diantaranya. Demikian pula untuk calon Kepala Daerah Tingkat II, calon disepakai antara Pimpinan DPRD II dengan Gubernur Kepala Daerah sedikitdikitnya 3 (tiga) orang dan sebanyak-banyaknya 5 (lima) orang (pasal 16 ayat h (1)), kemudian DPRD II memilih sedikit-dikitnya 2 (dua) orang diantara calon tersebut untuk diajukan kepada Menteri Dalam Negeri yang salah satunya akan ditetapkan menjadi kepala daerah (pasal 16 ayat (2)).

Sistem pemilihan kepala daerah tersebut menempatkan DPRD tidak dapat menentukan secara pasti siapa yang dikehendaki menjadi kepala daerah, hal ini wajar karena dalam undang-undang ini merupakan bagian dari pemerintah daerah. Konsekuensi dari hal tersebut, meskipun di dalam kontek normatif DPRD berkedudukan sejajar dengan kepala daerah, di dalam realitasnya DPRD berada dibawah kekuasaan eksekutif (Marijan, 2010). Oleh Karen itu realitanya bukan hasil pemilihan DPRD karena pada akhirnya bergantung dari penilaian Presiden, dengan demikian pemerintah pusatlah yang sesungguhnya mengendalikan pemerintah daerah.

Setelah reformasi semangat berbangsa dan bernegara berubah sangat mendasar, kekuasaan yang menumpuk di pusat dirubah menjadi desentralistik terpusat di Jakarta, hal ini tampak jelas dengan dikeluarkannya Undang-Undang Nomor 22 tahun 1999. Masa undang-undang ini kepala daerah sepenuhnya dipilih oleh DPRD, tidak ada campur tangan oleh pemerintah pusat Kepala Daerah dipilih oleh DPRD. pemilihan kepala daerah tersebut ternyata masih saja mengandung kelemahan, karena dalam mekanisme rekruitmen calon ditemukan banyak praktek politik uang. Calon kepala daerah selalu mengobral uang untuk membeli suara para anggota DPRD dalam pemilihan. Selain itu, juga mengeluarkan uang untuk membiayai kelompok-kelompok tertentu sebagai cara menciptakan opini public (viva. co.id, 2016).

Pemilihan kepala daerah tersebut berakhir setelah berlakunya Undang-Undang Nomor 32 tahun 2004 tentang Pemerintah Daerah, yang didalamnya mengatur pemilihan kepala daerah secara langsung yakni kepala daerah dipilih langsung oleh rakyat didaerahnya. Dengan demikian pemilihan langsung kepala daerah yang merupakan salah satu upaya untuk mengeliminir permainan politik uang, artinya jika ada yang mencoba melakukan politik uang tidak semudah yang dilakukan pada masa sebelumnya. Namun ternyata tidak semudah yang dibayangkan, kelihatannya masih belum berhasil dan politik uang masih berjalan terus. (Juanda, 2008).

Undang-undang Nomor 32 tahun 2004, ditetapkan bahwa dalam pencalonan kepala daerah dilakukan secara berpasangan sebagaimana disebutkan dalam pasal 56 bahwa, kepala daerah dan wakil kepala daerah berpasangan ini dimaksudkan untuk menghindari kemungkinan terjadinya konflik antara kepala daeran dengan wakilnya. pasangan calon tersebut diajukan oleh partai politik atau gabungan partai politik.

Undang-undang tersebut kemudian dirubah dengan Undang-undang Nomor 12 Tahun 2008, disamping pasangan calon yang diusung oleh partai politik diberikan kesempatan kepada perseorangan untuk mencalonkan diri. Sebagaimana disebutkan dalam konsideran Undang-undang Nomor 12 Tahun 2008 tersebut bahwa, undangundang ini dimaksudkan untuk melaksanakan amanat Undang-undang Dasar Negara Republik Indonesia Tahun 1945, penyelenggaraan pemerintahan daerah diarahkan agar mampu melahirkan kepemimpinan daerah yang efektif dengan memperhatikan prinsip demokrasi, persamaan, keadilan, dan kepastian hukum dalam sistem Negara Kesatuan Republik Indonesia. Disamping itu juga 
dalam rangka untuk mewujudkan kepemimpinan daerah yang demokratis yang memperhatikan prinsip persamaan dan keadilan, penyelenggaraan pemilihan kepala pemerintah daerah memberikan kesempatan yang sama kepada setiap warga negara yang memenuhi persyaratan.

\subsection{Berlakunya Undang Undang Nomor 23 Tahun 2014 Tentang Pemerintahan Daerah.}

Selajutnya setelah berlakunya Undang Undang Nomor 23 Tahun 2014 Tentang Pemerintahan Daerah, di dalamnya hanya memuat satu pasal yang mengatur pemilihan kepala daerah yakni, pasal 62 yang menyatakan, ketentuan mengenai pemilihan kepala daerah diatur dengan undang-undang. Berdasarkan ketentuan pasal 62 tersebut kemudian dikeluarkan Peraturan Pmerintah Pengganti Undang Undang Nomor 1 Tahun 2014 Tentang Pemilihan Gubernur, Bupati dan Walikota, yang kemudian ditetapkan menjadi Undang Undang Republik Indonesia Nomor 1 Tahun 2015 tentang Penetapan Peraturan Pemerintah Pengganti Undang Undang Nomor 1 Tahun 2014 tentang Pemilihan Gubernur, Bupati, dan Walikota menjadi Undang Undang. Belum genap satu tahun berjalan Undang Undang Nomor 1 Tahun 2015 ini kemudian dilakukan perubahan dengan Undang Undang Nomor 8 Tahun 2015 tentang Perubahan AtasUndang Undang Republik Indonesia Nomor 1 Tahum 2015 tentang Penetapan Peraturan Pemerintah Pengganti Undang Undang Nomor 1 Tahun 2014 tentang Pemilihan Gubernur, Bupati, dan Walikota Menjadi Undang Undang.

Disamping adanya persamaan-persamaan dengan undang-undang sebelumnya, terdapat beberapa perbedaan penting yang ada dalam Undang Undang Nomor 8 Tahun 2015. Pertama persyaratan Calon Gubernur dan Calon Wakil Gubernur, Calon Bupati dan Calon Wakil Bupati, serta Calon Walikota dan Wakil Walikota dalam pasal 7 disebutkan sebagai berikut:

Warga negara Indonesia yang dapat menjadi Calon Gubernur dan Calon Wakil Gubernr, Calon
Bupati dan Calon Wakil Bupati, serta Calon Walikota dan Calon Wakil Walikota adalah yang memenuhi persyaratan sebagai berikut:

a. bertakwa kepada Tuhan Yang Maha Esa;

b. setia kepada Pancasila, Undang-Undang Dasar Negara Repblik Indonesia Tahun 1945, cita-cita Proklamasi Kemerdekaan 17 Agustus 1945, dan Negara Kesatuan Republik Indonesia;

c. berpendidikan paling rendah sekolah lanjutan tingkat atas atau sederajat;

d. dihapus;

e. berusia paling rendah 30 (tiga puluh) tahun untuk Calon Gubernur dan Calon Wakil Gubernur serta 25 (dua puluh lima) tahun untuk Calon Bupati dan Calon Wakil Bupati serta Calon Walikota dan Calon Wakil Walikota;

f. mampu secara jasmani dan rohani berdasarkan hasil pemeriksaan kesehatan menyeluruh dari tim dokter;

g. tidak pernah dijatuhi pidana penjara berdasarkan putusan pengadilan yang telah memperoleh kekuatan hukum tetap karena melakukan tindak pidana yang diancam dengan pidana penjara 5 (lima) tahun atau lebih:

h. tidak sedang dicabut hak pilihnya berdasarkan putusan pengadilan yang telah mempunyai kekuatan hukum tetap;

i. $\quad$ tidak pernah melakukan perbuatan tercela yang dibuktikan dengan suratketerangan catatan kepolisian;

j. menyerahkan daftar kekayaan pribadi;

k. tidak sedang memiliki tanggungan utang secara perseorangan dan/atau secara badan hukum yang menjadi tanggung jawabnya yang merugikan keuangan negara;

l. tidak sedang dinyatakan pailit berdasarkan putusan pengadilan yang telah mempunyai kekuatan hukum tetap;

m. memiliki Nomor Pokok Wajib Pajak dan memiliki laporan pajak pribadi;

n. belum pernah menjabat sebagai Gubernur, Bupati, dan Walikota selama 2 (dua) kali masa jabatan yang sama untuk Calon Gubernur, Calon Bupati, dan Calon Walikota; 
o. belum pernah menjabat sebagai Gubernur, Bupati, dan Walikota untuk Calon Wakil Gubernur, Calon Wakil Bupati, dan Calon Wakil Walikota;

p. berhenti dari jabatannya bagi Gubernur, Wakil Gubernur, Bupati, Wakil Bupati, Walikota, dan Wakil Walikota yang mencalonkan diri di daerah lain sejak ditetapkan sebagai calon;

q. tidak berstatus sebagai pejabat Gubernur, penjabat Bupati, dan Penjabat Walikota;

r. tidak memiliki konflik kepentingan dengan petahana;

s. memberitahukan pencalonnya sebagai Gubernur, Wakil Gubernur, Bupati, Wakil Bupati, Walikota, dan Wakil Walikota kepada Pimpinan Dewan Perwakilan Rakyat bagi anggota Dewan Perwakilan Rakyat, kepada Pimpinan Dewan Perwakilan Daerah bagi anggota Dewan Perwakilan Daerah, atau kepada Pimpinan Dewan Perwakilan Rakyat Daerah bagi anggota Dewan Perwakilan Rakyat Daerah;

t. mengundurkan diri sebagai anggota Tentara Nasional Indonesia, Kepolisian Negara Republik Indonesia, dan Pegawai Negeri Sipil sejak mendaftarkan diri sebagai calon; dan

u. berhenti dari jabatan pada badan usaha milik negara atau badan usaha milik daerah sejak ditetapkan sebagai calon.

Kedua, peserta pemilihan kepala daerah adalah Pasangan Calon Gubernur dan Calon Wakil Guernur, Pasangan Calon Bupati dan Wakil Bupati, serta pasangan Calon Walikota dan Calon Wakil Walikota. Disamping itu undang - undang ini juga memberikn kesempatan kepada peserta perseorangan yang didukung oleh sejumlah orang, ini berarti kembali kepada ketentuan yang ada didalam Undang Undang Nomor 12 Tahun 2008, sebab Peraturan Pemerintah Pengganti Undang Undang sebelumnya menetapkan bahwa peserta pemilihan kepala daerah adalah Calon Gubernur, Calon Bupati, serta Calon Walikota, artinya calon -calon tersebut tidak berpasang - pasangan dengan wakilnya.
Pasal 39 menyebutkan bahwa Peserta Pemilihan adalah, Pasangan Calon Gubernur dan Calon Wakil Gubernur, Pasangan Calon Bupati dan Calon Wakil Calon Bupati,serta Pasangan Calon Walikota dan Calon Wakil Walikota, dan juga adanya peserta dari pasangan calon perseorangan yang didukung oleh sejumlah orang.

Syarat bagi Partai Politik atau Gabungan Partai Politik untuk dapat mencalonkan pasangan calon sebagaimana disebutkan dalam pasal 40, jika memperoleh suara paling sedikit $20 \%$ dari jumlah DPRD atau 25\% dari akumulasi perolehan suara sah dalam pemilihan umum anggota Dewan Perwakilan Rakyat Daerah di daerah yang bersangkutan.

Untuk peserta perseorangan persyaratannya dituangkan di dalam pasal 41 baik untuk Pasangan Calon Gubernur dan Wakil Gubernur maupun untuk Pasangan Calon Bupati dan Wakil Bupati serta Pasangan Calon Walikota dan Wakil Walikota.

Calon perseorangan dapat mendaftarkan diri sebagai Calon Gubernur dan Calon Wakil Gubernur jika memenuhi syarat dukungan dengan ketentuan:

a. provinsi dengan jumlah penduduk sampai dengan 2.000.000 (dua juta) jiwa harus didukung paling sedkit 10\% (sepuluh persen);

b. provinsi dengan jumlah penduduk lebih dari 2.000.000 (dua juta) jiwa samai dengan 6.000.000 (enam juta) jiwa harus didukung paling sedikit 8,5\% (delapan setengah persen);

c. provinsi dengan jumlah penduduk lebih dari 6.000 .000 (enam juta) jiwa sampai dengan 12.000 .000 (duableas juta) jiwa harus didukung paling sedikit 7,5\% (tujuh setengah persen);

d. provinsi dengan jmlah penduduk lebih dari 12.000.000 (dua belas juta) jiwa harus didukung paling sedikit 6,5\% (enam setengah persen); dan

e. jumlah dukungan sebagaimana dimaksud pada huruf a, huruf b, huruf $c$, dan hurufd tersebar di lebih dari 50\% (lima puluh persen) jumlah kabupaten/kota di Provinsi dimaksud. 


\section{Dinamika Pemilihan Kepala Daerah Berdasarkan Peraturan Perundang-Undangan di Indonesia}

Husein Muslimin

Calon perseorangan dapat mendaftarkan diri sebagai Calon Bupati dan Calon Wakil Bupati serta Calon Walikota dan Calon Wakil Walikota, jika memenuhi syarat dukungan dengan ketentuan:

a. Kabupaten/kota dengan jumlah penduduk sampai dengan 250.000 (dua ratus lima puluh ribu) jiwa harus didukung paling sedikit 10\% (sepluh persen);

b. Kabupaten/kota dengan jumlah penduduk lebih dari 250.000 (dua ratus lima puluh ribu) sampai dengan 500.000 (lima ratus ribu) jiwa harus didukung paling sedikit 8,5\% (delapan setengah persen);

c. Kabupaten/kota dengan jumlah penduduk lebih dari 500.000 (lima ratus ribu) sampai dengan 1.000.000 (satu juta) jiwa harus didukung paling sedikir 7,5\% (tujuh setengah persen);

d. Kabupaten/kota dengan jumlah penduduk lebih dari 1.000 .000 (satu juta) jiwa harus di dukung paling sedikit 6,5\% (enam setengah persen); dan

e. Jumlah dukungan sebagaimana dimaksud pada huruf a, huruf b, huruf $c$, dan huruf d tersebar di lebih dari 50\% (lima pluh persen) jumlah kecamatan di kabupaten/kota dimaksud.

Ketiga, ada respon atau solusi terhadap persoalan yang selama ini terjadi yang sudah menjadi rahasia umum yakni adanya mahar yang harus disetorkan kepada partai politik pengusung calon sehingga biaya yang dikeluarkan calon menjadi sangat besar, yang dapat menjadi salah satu sebab timbulnya korupsi. Pasal 47 antara lain menyebutkan bahwa, partai politik atau gabungan partai politik dilarang menerima imbalan dalam bentuk apapun pada proses pencalonan Gubernur dan Wakil Gubernur, Bupati dan Wakil Bupati, serta Walikota dan Wakil Walikota.

Partai Politik atau gabungan Partai Politik terbukti menerima imbalan, Partai Politik atau gabungan Partai Politik yang bersangkutan dilarang mengajukan calon pada periode berikutnya di daerah yang sama. Partai politik atau gabungan partai politik yang menerima imbalan harus dibuktikan dengan putusan pengadilan yang telah memper- oleh kekuatan hukum tetap. Keempat, salah satu aspek penting penyelenggaraan pemilihan dalam undang-undang ini adalah adanya efisiensi waktu dan anggaran, oleh karena itu kemudian diciptakan sistem pemilihan satu putaran sedemikian rupa dengan tetap memperhatikan legitimasi calon terpilih.

Di dalam Undang-undang ini dtetapkan bahwa pasangan calon yang memperoleh suara terbanyak ditetapkan sebagai calon terpilih. Pasal 107ayat (1) menyebutkan bahwa, pasangan Calon Bupati dan Calon Wakil Bupati serta pasangan Calon Walikota dan Calon Wakil Walikota yang memperoleh suara terbanyak ditetapkan sebagai pasangan Calon Bupati dan Calon Wakil Bupati terpilih, serta pasangan Calon Walikota dan Calon Wakil Walikota terpilih.Demikian juga pasal 109 ayat (1), menyebutkan untuk pasangan Calon Gubernur dan Calon Wakil Gubernur yang memperoleh suara terbanyak ditetapkan sebagai pasangan Calon Gubernur dan Wakil Gubernur terpilih.

Kelima, dimunculkannya lembaga yang menangani perselisihan hasi pemilihan yang wewenangnya pernah diberikan kepada Mahkamah Agung dan selanjutnya melalui peraturan yang berlaku wewenang tersebut berada pada Mahkamah Konstitusi. Dalam pasal 157 disebutkan bahwa, perkara perselisihan hasil Pemilihan diperiksa dan diadili oleh badan peradilan khusus, akan tetapi sebelum peradilan khusus tersebut terbentuk, perkara perkara perselisihan akan diperiksa dan diadili oleh Mahkamah Konstitusi.

Keenam, dalam hubungannya dengan pmilihan serentak secara nasional, Undang-undang ini memformulasikan tahapan menuju pemilihan serentak tersebut dengan mempertimbangkan pemotongan periode masa jabatan yang tidak terlalu lama, menyesuaikan dengan pelaksanaan Undangundang ini juga menyempurnakan beberapa ketentuan teknis yang terkait dengan penyelenggaraan pemilihan. Pasal 201 antara lain menyebutkan bahwa pemungutan suara serentak dalam Pemilihan 


\section{Jurnal Cakrawala Hukum, Volume 10 No. 1 Juni 2019}

ISSN PRINT 2356-4962 ISSN ONLINE 2598-6538

Gubernur dan Wakil Gubernur, Bupati dan Wakil Bupati, serta Walikota dan Wakil Walikota yang:

1. Masa jabatannya berakhir tahun 2015 dan bulan Januari sampai dengan bulan Juni tahun 2016 dilaksanakan pada bulan dan tanggal yang sama pada bulan Desember 2015;

2. Masa jabatannya berakhir pada bulan Juli sampai dengan bulan Desember tahun 2016 dan yang masa jabatannya berakhir pada tahun 2017 dilaksanakan pada tanggal dan bulan yang sama pada bulan Februarn tahun 2017;

3. Masa jabatannya berakhir pada tahun 2018 dan tahun 2019 dilaksanakan pada tanggal dan bulan Juni 2018;

4. Dihasilkan dari pemilihan 2015 dilaksanakan pada tahun 2020;

5. Dihasilkan dari peilihan tahun 2017 dilaksanakan pada tahun 2022;

6. Dihasilkan dari pemilihan tahun 2018 dilaksanakan pada tahun2023.

Pemungutan suara serentak nasional dalam Pemilihan Gubernur dan Wakil Gubernur, Bupati dan Wakil Bupati, serta Walikota dan Wakil Walikota di seluruh wilayah Negara Kesatuan Republik Indonesia dilaksanakan pada tanggal dan bulan yang sama pada tahun 2027.

\section{Simpulan}

Lahirnya Undang Undang Nomor 32 Tahun 2004 menggantikan Undang Undang Nomor 22 Tahun 1999 membawa perubahan yang sangat signifikan terhadap pemilihan kepala daerah, Kepala Daerah dipilih secara langsung oleh rakyat yang calonnya berpasangan dengan wakilnya dan diusulkan atau diusung oleh partai politik dengan syarat tertentu. Undang Undang ini kemudian dirubah dengan Undang Undang Nomor 12 Tahun 2008 yang memberikan kesempatan kepada peserta dari perseorangan untuk menjadi pasangan calon kepala daerah.Undang Undang ini dimaksudkan untuk meningkatkan kualitas demokrasi dan peranserta masyarakat dalam pembangunan di daerah, disamping dimaksudkan untuk menghilangkan atau setidak - tidaknya untuk mengurangi politik uang. Ternyata sistem ini memerlukan biaya yang sangat besar, termasuk biaya yang harus ditanggung oleh pasangan calon, sehingga pada saatnya justru menimbulkan korupsi di daerah, hal ini ditandai dengan maraknya kepala daerah yang ditangkap oleh Komisi Pembrantasan korupsi karena kasus korupsi.

Dengan dikeluarkannya Undang Undang Nomor 23 Tahun 2014 sebagai pengganti Undang Undang Nomor 32 Tahun 2004 beserta perubahannya didalamnya hanya ada satu pasal yang mengatur pemilihan kepala daerah yakni pasal 62 yang isinya bahwa, pemilihan kepala daerah diatur dengan undang - undang. Berdasarkan pasal 62 tersebut dikeluarkanlah Undang Undang Nomor 8 Tahun 2015 tentang Perubahan Atas Undang Undang Nomor 1 Tahun 2015 tentang Penetapan Peraturan Pemerintah Pengganti Undang Undang Nomor 1 Tahun 2014 tentang Pemilihan Gubernur, Bupati, dan Walikota Mnjadi Undang Undang. Mengurangi biaya yang harus dikeluarkan oleh penyelenggara dilakukan penyederhanaan pemilihan dengan menetapkan hanya ada satu putaran, partai politik atau gabungan partai politik dilarang menerima imbalan dalam bentuk apapun dari pasangan calon kepala daerah.

\section{Daftar pustaka}

Attamimi, A. Hamid. S., 1990. Peranan Kpeutusan Presiden Republik Indonesia dalam Penyelenggaraan Pemerintahan Negara, Suatu studi analisis mengenai Keputusan Presiden yang berfungsi pengaturan alam kurun waktu PELITA I -PELITA IV. Jakarta. Sekretariat Negara R.I.

Azhary, Muhammad Tahir. 2003. Negara Hukum, Suatu studi tentang prinsip-prinsipnya dilihat dari segi Hukum Islam, Implementasinya pada periode Negara Madinah dan masa kini. Jakarta. Bulan Bintang. 


\section{Dinamika Pemilihan Kepala Daerah Berdasarkan Peraturan Perundang-Undangan di Indonesia}

Husein Muslimin

Juanda. 2008. Hukum Pemerintahan Daerah, Pasang Surut Hubungan Kewenangan Antara DPRD dan Kepala Daerah. Bandung. Alumni.

Marijan, Kacung. 2010. Sistem Politik Indonesia, Konsolidasi demokrasi pasca-Orde Baru. Jakarta. Prenada Media Group.

Muladi. 2005. Hak Asasi Manusia, Hakekat, konsep dan implikasinya dalam perspektif hukum dan masyarakat. Bandung. Refika Aditama.

Politik.news.viva.co.id/news/read/542375.

Rais, M Amien. 1986. Demokrasi dan Proses Politik. Jakarta. LP3ES.

Undang-Undang Republik Indone.sia Nomor 22 tahun 1999 tentang Pemerintahan Daerah.

Undang-Undang Republik Indonesia Nomor 12 tahun 2008 tentang Perubahan Kedua atas Undang-Undang Nomor 32 tahun 2004 tentang Pemerintahan Daerah.
Undang-Undang Republik Indonesia Nomor 18 tahun 1965 tentang Pokok-Pokok Pemerntahan Daerah.

Undang-Undang Republik Indonesia Nomor 23 tahun 2014 tentang Pemerintahan Daerah.

Undang-Undang Republik Indonesia Nomor 32 tahun 2004 tentang Pemerintahan Daerah.

Undang-Undang Republik Indonesia Nomor 5 tahun 1974 tentang Pokok-Pokok Pemerintahan di Daerah.

Undang-Undang Republik Indonesia Nomor 8 tahun 2015 tentang Perubahan Atas Undang-Undang Republik Indonesia Nomor 1 tahun 2015 tentang Penetapan Peraturan Pemerintah Pengganti UndangUndang Nomor 1 tahun 2014 tentang Pemilihan Gubernur, Bupati, dan Walikota Menjadi UndangUndang. 